Pesq. Vet. Bras. 36(6):503-508, junho 2016 DOI: $10.1590 / \mathrm{S} 0100-736 \mathrm{X} 2016000600007$

\title{
Phenotypic and molecular detection of Salmonella sp. on growing, rearing and production phases in a commercial group of laying hens ${ }^{1}$
}

\begin{abstract}
Dunya M.C. Moraes ${ }^{2}$, Maria A. Andrade ${ }^{2}$, Sabrina C. Duarte ${ }^{3}$, Thiago S.A. Bastos $^{2 *}$, Emmanuel Arnhold ${ }^{2}$, Valéria de S. Jayme ${ }^{2}$ and Iolanda Aparecida Nunes ${ }^{2}$

ABSTRACT.- Moraes D.M.C., Andrade M.A, Duarte S.C., Bastos T.S.A., Arnhold E., Jayme V.S. \& Nunes J.A. 2016. Phenotypic and molecular detection of Salmonella sp. on growing, rearing and production phases in a commercial group of laying hens. Pesquisa Veterinária Brasileira 36(6):503-508. Departamento de Medicina Veterinária Preventiva, Escola de Veterinária e Zootecnia, Universidade Federal de Goiás, Campus Samambaia, Avenida Esperança s/n, Campus Universitário, Goiânia, GO 74690.900, Brazil. E-mail: tsabvet@gmail.com

This present study was developed with the objective of detect Salmonella sp. by conventional bacteriology and qPCR techniques in samples of flooring material from transport crates (meconium); raising environment (swab of cages and drinking fountains); cloacal swab; food and insects from growing, rearing and production phases in a commercial group of laying hens. A total of 864 samples were collected, among whom 248 originated from growing, 392 from rearing and 224 from production phase. Among the 864 samples, 2,8\% where positives in bacteriologic technique and $15.3 \%$ in qPCR. Contamination was higher in growing and rearing phases and declined in production phase. Twenty four isolations of Salmonella where typified as Salmonella Agona (41.7\%), Salmonella Livingstone (33.3\%), Salmonella Cerro (16.7\%), Salmonella Senftenberg (4.2\%) and Salmonella Schwarzengrund (4.2\%). During growing phase Salmonella Livingstone was identified. These findings suggest vertical contamination in the group. During rearing and production phases, isolated materials belong to serovars Agona, Cerro, Senftenberg and Schwarzengrund, pointing to horizontal contamination. It is possible to conclude that both vertical and horizontal contaminations are important during the cycle of commercial egg production and contamination in rearing phase is higher than in growing and production phases.
\end{abstract}

INDEX TERMS: Alphitobius diaperinus, bacteriology, cage flooring, environment, qPCR.

RESUMO-- [Detecção fenotípica e molecular de Salmonella sp. nas fases de cria, recria e produção em lote de poedeiras comerciais.] 0 presente estudo foi desenvolvido com objetivo de detectar Salmonella sp. pelas técnicas de bacteriologia convencional e PCR em tempo real em amostras de forros de caixas de transporte (mecônio), de ambientes de criação (suabes de gaiola e de bebedouro), suabes de cloaca, ração e insetos oriundos das fases de cria, recria e

\footnotetext{
'Received on April 22, 2015.

Accepted for publication on May 10, 2016.

${ }^{2}$ Departamento de Medicina Veterinária Preventiva, Escola de Veterinária e Zootecnia, Universidade Federal de Goiás (UFG), Campus Samambaia, Avenida Esperança s/n, Campus Universitário, Goiânia, GO 74690.900, Brazil. *Corresponding author: tsabvet@gmail.com

${ }^{3}$ Embrapa Suínos e Aves, Rodovia BR-153 Km 110, Distrito de Tamanduá, Cx. Postal 21, Concórdia, SC 89700-000, Brazil.
}

produção de um lote de poedeiras comerciais. Foram coletadas 864 amostras das quais 248 foram originadas da cria, 392 da recria e 224 da produção. Das 864 amostras 2,8\% foram positivas na técnica bacteriológica e 15,3\% no PCR em tempo real. A contaminação aumentou da fase de cria para a recria e declinou na fase de produção. Vinte e quatro isolados de Salmonella foram tipificados como Salmonella Agona (41,7\%), Salmonella Livingstone (33,3\%), Salmonella Cerro (16,7\%), Salmonella Senftenberg (4,2\%) e Salmonella Schwarzengrund $(4,2 \%)$. Na fase de cria identificou-se Salmonella Livingstone. Esses achados sugerem a contaminação vertical do lote. Nas fases de recria e produção os isolados pertenceram aos sorovares Agona, Cerro, Senftenberg e Schwarzengrund apontando para a contaminação horizontal. Pode-se concluir com este estudo que tanto a contaminação vertical como a horizontal são importantes no ciclo de 
produção de ovos comerciais e que a contaminação na fase de recria é maior que na fase de cria e de produção.

TERMOS DE INDEXAÇÃO: Alphitobius diaperinus, ambiente, bacteriologia, forros de caixa, PCR em tempo real.

\section{INTRODUCTION}

Bacteria of genus Salmonella are among the most notorious pathogens in the commercial poultry industry. Its worldwide distribution and serovars with zoonotic potential have been associated with human toxicosis by ingestion of contaminated food.

Mughini-Gras et al. (2014), when studying the probable risk factors of human salmonellosis caused by pork, beef, chicken and eggs, concluded that chicken and eggs are the most incriminated origin of human infections in urban areas during the warmest months of the year. Also, according to Téo \& de Oliveira (2005), eggs and poultry meat are the most contaminated products with Salmonella, and the egg is the main introduction source of Salmonella into the human food chain (Singh et al. 2010).

The spread of Salmonella sp. in the poultry production flow can occur through vertical transmission, by using day-old infected chicks, and horizontal transmission, by being exposed to contaminated food and environment (Cox, Berrang \& Cason 2000, Gantois et al. 2009). To Frederick \& Huda (2011) the majority of infections caused by Salmonella sp. in commercial laying hens are associated with environmental contamination, mainly through contaminated water and food. In addition, Braden (2006) considered that farms are favorable to the maintenance of this pathogen and cages, dust, insects, equipment or components in a shed can be pointed out as potential sources of contamination.

Brazilian National Plan for Avian Health (PNSA - Plano Nacional de Sanidade Avícola) defines methods of diagnosis, control and monitoring of Salmonella sp according to animal category and purpose of production (Brasil 1994). The monitoring of Salmonella Enteritidis and Salmonella Typhimurium in commercial layer farms and the use of live vaccine for Salmonella Enteritidis, in the hatchery or in the rearing phases, was later established by Normative Instruction no.10, published on April 11, 2013 by the Brazilian Ministry of Agriculture Livestock and Supply (MAPA).

For the monitoring of Salmonella sp. in samples originated from different sources, conventional bacteriology is the officially recommended technique (Brasil 1994). However, molecular techniques, such as quantitative PCR (qPCR), have been developed to allow diagnosis in a shorter period of time.

Considering the above, the present study was developed to investigate the presence of Salmonella sp., using the techniques of conventional bacteriology and qPCR, on samples of meconium, environmental swabs, cloacal swabs, food and insects collected in the phases of growing, rearing and production of laying hens.

\section{MATERIALS AND METHODS}

\section{Study site}

The experiment was conducted at the Bacteriology Laboratory and Molecular Diagnostics Laboratory, from the Department of Veterinary Medicine at the Escola de Veterinária e Zootecnia from the Federal University of Goiás.

\section{Sampling}

Samples were obtained from a group of laying hens housed in a laying farm during 2012 and 2013.

Growing phase. Twenty-eight meconium samples were collected immediately after the withdrawal of chicks from the shipping boxes. Each sample contained approximately $500 \mathrm{~g}$ of transport crates liners that were collected randomly from 20 boxes. When hens reached five weeks old, were collected: 48 samples of cloacal swabs, 76 cage swabs, 24 swabs from drinking fountains, 48 samples of flies and 24 samples of feed. Each swab sample consisted of a 20-swab pool and each feed sample consisted of $500 \mathrm{~g}$ of feed. Cages and drinking fountains swabs were soaked in $1 \%$ peptone water and after rubbed on the bars of the cages and drinking fountains. Swab samples were placed in transport pouches containing $70 \mathrm{ml}$ of $1 \%$ peptone water, kept cooled in ice boxes and sent to the laboratory. Flies were caught in glue traps suited for this procedure. These flies, in the laboratory, were macerated with a sterilized glass rod and $1 \mathrm{~g}$ of the material was placed in $9 \mathrm{~mL}$ of $1 \%$ peptone water. The feed samples were collected directly from the feeders and packed in plastic bags. At this phase, a total of 248 samples were collected.

Rearing phase. When hens reached 13 weeks old, they were transported to other sheds. Using the same procedure described before, 96 cage swabs, 96 drinking fountain swabs, 96 cloacal swabs, 72 feed samples and 16 flies were collected. Also, 16 samples of mealworms per shed were collected with the aid of sterilized stainless steel forceps. Each one consisted of insects collected in three rows of sheds. All samples were refrigerated and sent to the laboratory, except for insects, which were transported at room temperature in plastic bags. In the laboratory these mealworms were macerated with a sterilized glass rod, and $1 \mathrm{~g}$ of the material was placed in $9 \mathrm{~mL}$ of $1 \%$ peptone water. A total of 392 samples were collected from different sources.

Production Phase. Using the same procedures of the growing and rearing phases, 48 cloacal swabs from 45 -week-old hens, 48 cage swabs, 48 drinking fountains swabs, 48 feed samples, 16 fly samples and 16 mealworm samples were collected. The same precautions were adopted. In the production phase, 224 samples were collected. In the laboratory, all samples were processed according to Brasil (2003).

\section{Conventional bacteriology for Salmonella sp. detection.}

Samples of $1 \%$ peptone water were incubated at $37^{\circ} \mathrm{C} / 18$ $-20 \mathrm{~h}$. After this, they were homogenized and $1 \mathrm{~mL}$ was transferred into $9 \mathrm{~mL}$ of Selenite Cystine Broth (SC) and $1 \mathrm{~mL}$ to $10 \mathrm{~mL}$ of Rappaport Vassiliadis broth (RV) followed by incubation at $37^{\circ} \mathrm{C} / 24 \mathrm{~h}$. Aliquots of $2 \mathrm{~mL}$ of SC were placed in eppendorf tubes and stored at $-20^{\circ} \mathrm{C}$ for qPCR. After that, with a nickel-chrome inoculation loop, aliquots were streaked on the surface for agars: XLT4, Hektoen and brilliant green, and incubated at $37^{\circ} \mathrm{C} / 24 \mathrm{~h}$. Colony-forming Units (CFU) with morphological characteristics of Salmonella were selected and three to five CFU per plate were transferred to tubes containing triple sugar iron agar (TSI) and incubated at $37^{\circ} \mathrm{C} / 24 \mathrm{~h}$. TSI cultures with Salmonella suggestive growth were subjected to urease test, indole production, methyl red, motility, lysine descarboxylase, malonate test and Simmons citrate agar test. When biochemical tests were compatible with Salmonella, the samples were subjected to serological tests with polyvalent 0 antisera; and the positive ones were referred to the Oswaldo Cruz Foundation (Fiocruz-RJ) on nutrient agar for serological typing. 


\section{Quantitative PCR research of Salmonella sp.}

Before the extraction procedure, the frozen samples in SC Broth were subjected to a new bacterial enrichment using $9 \mathrm{~mL}$ of SC broth. Total DNA was isolated by boiling lysis (Santos et al. 2001). A $400 \mu \mathrm{L}$ of sample was used in a $1.5 \mathrm{~mL}$ polypropylene tube free of DNA and RNA (Axygen). The tube containing the sample was centrifuged at 2,000G for four minutes. The supernatant was discarded and suspended in $1 \mathrm{~mL}$ of TE $(100 \mathrm{~mL}$ Tris/HcL $1 \mathrm{~m}+20 \mu \mathrm{L}$ of EDTA $0.5 \mathrm{~m}+9.880 \mu \mathrm{L} \mathrm{H}_{2} \mathrm{O}$ ). The sample was mixed by vortexing for ten seconds and centrifuged at 1956.2G for eight minutes. After discarding the supernatant, the pellet was suspended in $100 \mu \mathrm{L}$ of TE. The mixture was washed in the vortex for ten secon$\mathrm{ds}$ and placed on a hotplate at $95^{\circ} \mathrm{C}$ for 20 minutes, aliquoted and stored at $-20^{\circ} \mathrm{C}$ in a freezer for later use.

qPCR assays for the detection of Salmonella sp. were performed according to Calvó et al. (2008). The eluates obtained from extracted samples were used for qPCR with the TaqMan ${ }^{\circledR}$ system. The volume of $20 \mu \mathrm{L}$ was used, with $4.6 \mu \mathrm{L}$ of milli-Q water, $10 \mu \mathrm{L}$ of Master Mix (1x), $2 \mu \mathrm{L}$ of IPC mix (10x), $0.4 \mu \mathrm{L}$ of IPC DNA (50x) and $1 \mu \mathrm{L}$ of oligonucleotide primers (concentration $30 \mathrm{mM}$ ) and probe (concentration of $10 \mathrm{mM}$ ) adding $2 \mu \mathrm{L}$ of DNA samples. As a reaction internal control an IPC reagent blocker (negative control blocked IPC, Life ${ }^{\circledR}$ ) and IPC DNA without blocking were used. Samples were tested for presence/absence in StepOnePlus ${ }^{\mathrm{TM}}$ qPCR System (Applied Biosystems) under the following conditions: pre PCR at $60^{\circ} \mathrm{C}$ for 30 seconds, followed by $95^{\circ} \mathrm{C}$ for 10 minutes, than 40 cycles at $95^{\circ} \mathrm{C}$ for 15 seconds (denaturation step) followed by $60^{\circ} \mathrm{C}$ for 1 minute and $60^{\circ} \mathrm{C}$ for 30 seconds for extension step.

To detect Salmonella sp. by qPCR, the TaqMan ${ }^{\circledR}$ system was used, applying oligonucleotide primers SAL1410f 5'-GGTCTGCTGTACTCCACCTTCAG-3' and SAL1494r 5'-TTGGAGATCAGTACGCCGTTCT-3' and probe SAL1441pr FAM- TTACGACGATATTCGTCCGGGTGAAGTG - TAMRA, developed by Calvó et al. (2008). Results were analyzed using StepOne Software v2.1 (Applied Biosystems), with 95\% confidence level.

\section{Statistical analysis.}

Result interpretation was made using Binomial Distribution analysis with R Statistical Software (Core Team 2015).

\section{RESULTS AND DISCUSSION}

Results of the 864 samples analyzed are recorded in Table 1. On conventional bacteriology $24 / 864$ (2.8\%) samples were positive for Salmonella sp. and 132/864 (15.3\%) samples in qPCR. Bacteria were detected by the conventional bacteriology in $7 / 220$ (3.2\%) of cage swabs, in 5/168 (3.0\%) of drinking fountain swabs, in 3/192 (1.6\%) of cloacal swabs, in 5/144 (3.5\%) of feed samples, in 3/80 (3.7\%) of fly samples (Musca domestica) and in 1/28 (3.6\%) of samples from crate liner. None mealworm samples (Alphitobius diaperinus) showed bacteria when using the conventional technique of bacteriology. By qPCR, Salmonella sp. were found in $36 / 220$ (16.4\%) of cage swabs, in 24/168 $(14,3 \%)$ of drinking fountain swabs, in 40/192 (20.8\%) of cloacal swabs, in $14 / 144(9.7 \%)$ of feed samples, in 8/80 $(10.0 \%)$ of fly samples (Musca domestica), in 8/32 (25.0\%) mealworm samples (Alphitobius diaperinus) and in 2/28 (7.1\%) of samples from crate liner. In all sample categories, higher percentage of Salmonella sp. detection occurred by qPCR.

Cage swabs showed the highest contamination on CB $(3.2 \%)$ and the third highest value $(16.4 \%)$ on qPCR. Poul-
Table 1. Frequency (\%) of Salmonella sp. on samples of commercial poultry production system analyzed by conventional bacteriological (CB) and qPCR

\begin{tabular}{lccc}
\hline Sample category & $\mathrm{n}$ & $\mathrm{CBn}+(\%)$ & $\mathrm{qPCR} \mathrm{n}+(\%)$ \\
\hline Cage swab & 220 & $7 / 220(3.2 \%)$ & $36 / 220(16.4 \%)$ \\
Drinking fountain swab & 168 & $5 / 168(3.0 \%)$ & $24 / 168(14.3 \%)$ \\
Cloacal swab & 192 & $3 / 192(1.6 \%)$ & $40 / 192(20.8 \%)$ \\
Feed & 144 & $5 / 144(3.5 \%)$ & $14 / 144(9.7 \%)$ \\
Flies & 80 & $3 / 80(3.7 \%)$ & $8 / 80(10.0 \%)$ \\
Mealworms & 32 & - & $8 / 32(25 \%)$ \\
Crate liner & 28 & $1 / 28(3.6 \%)$ & $2 / 28(7.1 \%)$ \\
TOTAL (\%) & 864 & $24 / 864(2.8 \%)$ & $132 / 864(15.3 \%)$
\end{tabular}

try production in cages may be a risk factor for contamination of laying hens by Salmonella sp. The continued use of cages for years, housing different batches without prior and proper cleaning and absence of gradual depopulation, can be associated with presence and maintenance of Salmonella in the environment. Such observances are supported by Namata et al. (2008) and Van Hoorebeke et al. (2011).

Results from samples of drinking fountain swabs analyzed by $\mathrm{CB}(3.0 \%)$ were similar to the percentage reported by Singh et al. (2013), 3.3\% from laying hens drinking water, however, superior to those found by Bouzidi et al. (2012), $0.80 \%$. Contamination levels of cage (16.4\%) and drinking fountain (14.3\%) swabs found by qPCR in this research strengthen the findings of Marin, Hernandiz \& Lainez (2009), who believe in the ability of some serovars forming biofilm on the premises of commercial layer farms and that cleaning and disinfection procedures do not eliminate this microorganism.

Salmonella sp. detection by CB in cloacal swabs (1.6\%) were lower than those reported by Singh et al. (2013), who have found 4.4\%, and by García et al. (2011), which 4\% of cloacal swabs were positive for this bacteria. Cloacal swabs used as samples to monitor the presence of Salmonella by conventional bacteriology present limitations. This pathogen has the ability of being intermittently secreted and can be disposed in small amounts in feces (Andrade et al. 2009); However, qPCR detected $20.8 \%$, which suggests that the method used to identify pathogens affects results, especially when there is a minimal contamination.

Salles et al. (2008) did not isolate Salmonella in 40 samples of meconium from shipping crates. Differently, in this study Salmonella sp. was found in $3.6 \%$ and $7.1 \%$ of meconium samples from CB and qPCR, respectively. The low positivity rate in meconium can be justified by Van Immerseel et al. (2004) who have associated the weakened vertical contamination of Salmonella sp. in poultry with continuous vaccination and hygiene measures, besides strict disinfection.

The majority of infections caused by Salmonella sp. in commercial laying hens arose from environmental contamination, mainly through contaminated water and food (Frederick \& Huda 2011). In feed samples (3.5\% by CB), the results was similar to Singh et al. (2013), that have found $2.5 \%$.

According to Liebana et al. (2003), flies and mealworm are insects very relevant to the epidemiological chain of salmonellosis and have contributed to the maintenance 
and spreading of the agent in poultry environment. One of the factors that facilitate the proliferation of flies is the accumulation of large amounts of manure (Carrique-Mas et al. 2009). When these flies are exposed to Salmonella contaminated environments, they may become infected and transmit the bacteria to housed poultry (Holt et al. 2007). Also, the ingestion of contaminated A. diaperinus larvae or adult with Salmonella can infect hens (Roche et al. 2009). This mechanical vector can be a serious problem for poultry producers because it feeds on dying birds, carcasses, faeces and feed, and may remain weeks in the poultry facilities, thus contaminating successive groups (Hazeleger et al. 2008, Leffer et al. 2010).

Olsen \& Hammack (2000) found $22 \%$ positive samples for Salmonella sp. of flies collected in commercial poultry environment, a much higher level of contamination than that described in this study: M. domestica were $3.7 \%$ positive for Salmonella by CB and $10.0 \%$ by qPCR..

Like this study, were $A$. diaperinus only showed detection by qPCR (25\%), Chernaki-Leffer et al. (2002) failed to isolate Salmonella sp. from A. diaperinus samples by CB in broiler farms and Segabinazi et al. (2005) recorded only $0.37 \%$ positive results for Salmonella sp. in 54 mealworm samples. However, Hald, Olsen \& Madsen (1998) found Salmonella sp. in $45 \%$ in mealworm samples, collected from broiler farms during group entering and leaving interval, confirming the potential risk of contamination for further groups.

In this study, the serovars identified were: Salmonella Livingstone during the growing phase, Salmonella Agona, Salmonella Cerro and Salmonella Senftenberg during the rearing phase and, during the production phase, Salmonella Schwarzengrund (Table 2).

Salmonella Livingstone were detected in meconium collected from crate liners on housing, in cage and drinking fountains swabs (in the fifth week) and in flies. These results suggest its introduction in the shed by vertical channels and spread in the environment, like observed by Holt et al. (2007) after inoculate Salmonella Enteritidis in laying hens and collect $50 \%$ of the flies infected in the same environment. Moreover, the absence of Salmonella Livingstone on the remaining samples of rearing and production phases was probably due to the development of the immune system and the establishment of the normal intestinal microflora, which promoted elimination or reduction of bacteria levels. This occurrence is supported by Van Immerseel et al. (2004), who have reported that newly hatched chicks can be infected by Salmonella, because they have immature immune system and a higher level of excretion of bacteria during their first weeks of life.

Salmonella Agona and Salmonella Cerro were isolated in cages, drinking fountains, cloacal and feed swabs. These findings indicate the spread of pathogens by horizontal transmission, but it is difficult to establish the source of contamination (Hinton 1988). Since the persistence of Salmonella in the environment is an important feature in its epidemiology, hens may be infected during growing phase (Carrique-Mas et al. 2009), by being in contact with inoculated hens (Thomas et al. 2009), with confirm the complex epidemiology of Salmonella infections (Hinton 1988).
Salmonella Senftenberg and Salmonella Schwarzengrund has been found only in feed in the rearing phase and only in feed during the production phase, respectively. These serovars can survive for long periods of time in a latent state and, during favorable conditions, they can multiply and infect hens.

Salmonella Enteritidis were not found in the analyzed samples, but Temelli et al. (2010) have found Salmonella Enteritidis as the most isolated serovar 49/75 (65.3\%) in samples of cloacal swabs.

Table 2. Frequency (\%) of Salmonella serovars in samples collected in laying hen farm in the phases of growing, rearing and production, by conventional bacteriology (CB)

\begin{tabular}{|c|c|c|c|}
\hline \multirow[t]{2}{*}{ Sample category } & \multicolumn{2}{|r|}{ Growing phase } & \multirow[t]{2}{*}{ Serovars } \\
\hline & $\mathrm{n}$ & $\mathrm{CB} n+(\%)$ & \\
\hline Meconium & 28 & $1 / 28(3.6 \%)$ & $\begin{array}{c}\text { Salmonella } \\
\text { Livingstone }(1 / 1)\end{array}$ \\
\hline Cage swab & 76 & $3 / 76(3.9 \%)$ & $\begin{array}{c}\text { Salmonella } \\
\text { Livingstone }(3 / 3)\end{array}$ \\
\hline Drinking fountain swab & 24 & $1 / 24(4.2 \%)$ & $\begin{array}{c}\text { Salmonella } \\
\text { Livingstone }(1 / 1)\end{array}$ \\
\hline Cloacal swab & 48 & -* & - \\
\hline Feed & 24 & - & - \\
\hline Flies & 48 & $3 / 48(6.3 \%)$ & $\begin{array}{c}\text { Salmonella } \\
\text { Livingstone }(3 / 3)\end{array}$ \\
\hline Sample category & $\mathrm{n}$ & $\begin{array}{c}\text { Rearing phase } \\
\text { CB n }+(\%)\end{array}$ & Serovars \\
\hline Cage swab & 96 & $4 / 96(4.2 \%)$ & $\begin{array}{c}\text { Salmonella Agona }(3 / 4) \\
\text { Salmonella Cerro }(1 / 4)\end{array}$ \\
\hline Drinking fountain swab & 96 & $4 / 96(4.2 \%)$ & $\begin{array}{c}\text { Salmonella Agona }(2 / 4) \\
\text { Salmonella Cerro }(2 / 4)\end{array}$ \\
\hline Cloacal swab & 96 & $3 / 96(3.1 \%)$ & Salmonella Agona (3/3) \\
\hline Feed & 72 & $4 / 72(5.5 \%)$ & $\begin{array}{c}\text { Salmonella Agona }(2 / 4) \\
\text { Salmonella Cerro }(1 / 4) \\
\text { Salmonella } \\
\text { Senftenberg }(1 / 4)\end{array}$ \\
\hline Flies & 16 & - & - \\
\hline Mealworms & 16 & $\begin{array}{l}\text { - } \\
\text { Production phase }\end{array}$ & - \\
\hline Sample category & $\mathrm{n}$ & $\mathrm{CB} n+(\%)$ & Serovars \\
\hline Cage swab & 48 & - & - \\
\hline Drinking fountain swab & 48 & - & - \\
\hline Cloacal swab & 48 & - & - \\
\hline Feed & 48 & $1 / 48(2.1 \%)$ & $\begin{array}{c}\text { Salmonella } \\
\text { Schwarzengrund (1/1) }\end{array}$ \\
\hline Flies & 16 & - & - \\
\hline Mealworms & 16 & - & - \\
\hline
\end{tabular}

Table 3. Results from binomial distribution in the phases of growing, rearing and production of a laying hen batch, by conventional bacteriology (CB) and qPCR

\begin{tabular}{lccc}
\hline Growing phase & $\mathrm{n}$ & $\mathrm{CB} \mathrm{n}+(\%)$ & $\mathrm{qPCR} \mathrm{n}+(\%)$ \\
\hline Growing & 248 & $8 / 248(3.2)$ & $18 / 248(7.2) \mathrm{A}$ \\
Rearing & 392 & $15 / 392(3.8)$ & $88 / 392(22.4) \mathrm{B}$ \\
$\mathrm{P}$ & - & 0,8573 & 0,000000839 \\
Rearing & 392 & $15 / 392(3.8) \mathrm{A}$ & $88 / 392(22.4) \mathrm{A}$ \\
Production & 224 & $1 / 224(0.4) \mathrm{B}$ & $26 / 224(11.6) \mathrm{B}$ \\
P & - & 0.02297 & 0.001258 \\
Growing & 248 & $8 / 248(3.2)$ & $18 / 248(7.2)$ \\
Production & 224 & $1 / 224(0.4)$ & $26 / 224(11.6)$ \\
$\mathrm{P}$ & - & 0.0618 & 0.1431
\end{tabular}

A,B means followed by different letters in the same column differ by Binomial Distribution $(\mathrm{P}<0.05)$. 
The absence of animal meal in feed composition during growing phase can justify absence of Salmonella sp. detection in feed samples. Animal meal is the main source of contamination (Albuquerque et al. 1999, Morita et al. 2006, Tacon \&Metian 2008).

Results of the Binomial Distribution, calculated pairwise, in samples collected in phases of growing, rearing and production, subjected to the CB and qPCR were exposed in Table 3. Between the phases of growing and rearing, there was no statistical difference in contamination of Salmonella sp. by CB, although there has been increased number of positive samples when using $\mathrm{qPCR}$, however, this condition has occurred with $\mathrm{P}<0.05$. When assessing only the phases of growing and production, there was no statistical difference in contamination between both tests. But, the rearing phase presented higher contamination than in the production phase $(\mathrm{P}<0.05)$ in both tests.

Hypothetically, these results suggest that vertical transmission of Salmonella occurred during the growing period, spread itself and the hens were able to eliminate this infection. After the fifth week, when hens were transferred to other sheds, they became infected again until 45th week, when this agent was no more recovered.

\section{CONCLUSIONS}

The presence of Salmonella Livingstone in chick batches can contaminate environment and insects, assisting its horizontal transmission. This serovar was only detected during the growing phase. Salmonella Agona, Salmonella Cerro and Salmonella Senftenberg were detected during the rearing phase and Salmonella Schwarzengrund during the production phase.

The qPCR technique proved to be more suitable than conventional bacteriology for the detection of Salmonella sp. in samples taken from laying hen production sheds.

\section{REFERENCES}

Albuquerque R., Ito N.M.K. \& Miyaji C.I. 1999. Estudo da ocorrência de salmonelas em ingredientes, rações e suabes de pó colhidos em uma fábrica industrial de ração. Braz. J. Vet. Res. Anim. Sci. 36:324-326.

Andrade M.A., Stringhini J.H., Mesquita A.J., Brito L.A.B., Chaves L.S. \& Mattos M.S. 2009. Aspectos clínicos e anatomohistopatológicos de pintos de corte oriundos de ovos inoculados experimentalmente com Salmonella Enteritidis fagotipo 4. Ciênc. Anim. Bras. 10:909-917.

Bouzidi N., Aoun L., Zeghdoudi M., Bensouilah M., Elgroud R., Oucief I., Granier S.A., Brisabois A., Desquilbet L. \& Millemann Y. 2012. Salmonella contamination of laying-hen flocks in two regions of Algeria. Food Res. Int. 45:897-904.

Braden C.R. 2006. Salmonella enterica serotype Enteritidis and eggs: a national epidemic in the United States. Clin. Infect. Dis. 43:512-517.

Brasil 1994. Portaria Ministerial no193, de 19 de Setembro de 1994. Programa Nacional de Sanidade Avícola (PNSA), Secretaria Nacional de Defesa Agropecuária, Ministério da Agricultura Pecuária e Abastecimento (MAPA), Brasília, DF.

Brasil 2003. Métodos de Análises Microbiológicas para Alimentos. Departamento Nacional de Defesa Animal. Coordenação Geral de Laboratório Animal, Secretaria Nacional da Defesa Agropecuária, Ministério da Agricultura Pecuária e Abastecimento (MAPA), Brasília, DF. 226p.

Calvó L., Martínez-Planells A., Pardos-Bosch J. \& Garcia-Gil L.J. 2008. A new real-time PCR assay for the specific detection of Salmonella spp. targeting the bipA gene. Food Analytical Methods 1:236-242.
Carrique-Mas J.J., Breslin M., Snow L., McLaren I., Sayers A.R. \& Davies R.H. 2009. Persistence and clearance of different Salmonella serovars in buildings housing laying hens. Epidemiol. Infect. 137:837-846.

Chernaki-Leffer A.M., Biesdorf S.M., Almeida L.M., Leffer E.V.B. \& Vigne F. 2002. Isolamento de enterobactérias em Alphitobius diaperinus e na cama de aviários no Oeste do Estado do Paraná, Brasil. Revta Bras. Ciênc. Avícola 4:243-247.

Core Team R. 2015. R: A language and environment for statistical computing. Foundation for Statistical Computing, Vienna, Austria. (ISBN 3-900051-07-0)

Cox N.A., Berrang M.E. \& Cason J.A. 2000. Salmonella penetration of egg shells and proliferation in broiler hatching eggs-a review. Poult. Sci. 79:1571-1574.

Frederick A. \& Huda N. 2011. Salmonellas, poultry house environments and feeds: a review. J. Anim. Vet. Advances 10:679-685.

Gantois I., Ducatelle R., Pasmans F., Haesebrouck F., Gast R., Humphrey T.J. \& Van Immerseel F. 2009. Mechanisms of egg contamination by Salmonella Enteritidis. FEMS Microbiol. Reviews 33:718-738.

García C., Soriano J.M., Benítez V. \& Catalá-Gregori P. 2011. Assessment of Salmonella spp. in feces, cloacal swabs, and eggs (eggshell and content separately) from a laying hen farm. Poult. Sci. 90:1581-1585.

Hald B., Olsen A. \& Madsen M. 1998. Typhaea stercorea (Coleoptera: Mycetophagidae), a carrier of Salmonella enterica serovar Infantis in a Danish broiler house. J. Econ. Entomol. 91:660-664.

Hazeleger W.C., Bolder N.M., Beumer R.R. \& Jacobs-Reitsma W.F. 2008. Darkling beetles (Alphitobius diaperinus) and their larvae as potential vectors for the transfer of Campylobacter jejuni and Salmonella enterica serovar Paratyphi B variant Java between successive broiler flocks. Appl. Environ. Microbiol. 74:6887-6891.

Hinton M. 1988. Salmonella infection in chicks following the consumption of artificially contaminated feed. Epidemiol. Infect. 100:247-256.

Holt P.S., Geden C.J., Moore R.W. \& Gast R.K. 2007. Isolation of Salmonella enterica serovar Enteritidis from houseflies (Musca domestica) found in rooms containing Salmonella serovar Enteritidis-challenged hens. Appl. Environ. Microbiol. 73:6030-6035.

Leffer A.M., Kuttel J., Martins L.M., Pedroso A.C., Astolfi-Ferreira C.S., Ferreira F. \& Ferreira A.J.P. 2010. Vectorial competence of larvae and adults of Alphitobius diaperinus in the transmission of Salmonella Enteritidis in poultry. Vector-borne and Zoonotic Diseases 10:481-487.

Liebana E., Garcia-Migura L., Clouting C., Clifton-Hadley F.A., Breslin M. \& Davies R.H. 2003. Molecular fingerprinting evidence of the contribution of wildlife vectors in the maintenance of Salmonella Enteritidis infection in layer farms. J. Appl. Microbiol. 94:1024-1029.

Marin C., Hernandiz A. \& Lainez M. 2009. Biofilm development capacity of Salmonella strains isolated in poultry risk factors and their resistance against disinfectants. Poult. Sci. 88:424-431.

Morita T., Kitazawa H., Iida T. \& Kamata S. 2006. Prevention of Salmonella cross-contamination in an oilmeal manufacturing plant. J. Appl. Microbiol. 101:464-473.

Mughini-Gras L., Enserink R., Friesema I., Heck M., van Duynhoven Y. \& van Pelt W. 2014. Risk factors for human salmonellosis originating from pigs, cattle, broiler chickens and egg laying hens: a combined case-control and source attribution analysis. PloS One 9:e87933.

Namata H., Méroc E., Aerts M., Faes C., Abrahantes J.C., Imberechts H. \& Mintiens K. 2008. Salmonella in Belgian laying hens: an identification of risk factors. Prev. Vet. Med. 83:323-336.

Olsen A.R. \& Hammack T.S. 2000. Isolation of Salmonella spp. from the housefly, Musca domestica L., and the dump fly, Hydrotaea aenescens (Wiedemann)(Diptera: Muscidae), at caged-layer houses. J. Food Protection 63:958-960.

Roche A.J., Cox N.A., Richardson L.J., Buhr R.J., Cason J.A., Fairchild B.D. \& Hinkle N.C. 2009. Transmission of Salmonella to broilers by contaminated larval and adult lesser mealworms, Alphitobius diaperinus (Coleoptera: Tenebrionidae). Poult. Sci. 88:44-48.

Salles R.P.R., Cardoso W.M., de Castro Teixeira R.S., de Siqueira A.A., da 
Silva E.E. \& de Castro S.B. 2008. Monitoramento bacteriológico para Salmonella sp. em poedeira comercial em diferentes fases de recria e produção de empresas avícolas da Região Metropolitana de Fortaleza. Ciênc. Anim. Bras. 9:427-432.

Santos L.R., Nascimento V.P., de Oliveira S.D., Flores M.L., Pontes A.P., Ribeiro A.R., Salle C.T. \& Lopes R.F. 2001. Polymerase chain reaction (PCR) for the detection of Salmonella in artificially inoculated chicken meat. Revta Inst. Med. Trop., São Paulo, 43:247-250.

Segabinazi S.D., Flôres M.L., Barcelos A.S., Jacobsen G. \& Eltz R.D. 2005. Bactérias da família Enterobacteriaceae em Alphitobius diaperinus oriundos de granjas avícolas dos Estados do Rio Grande do Sul e Santa Catarina, Brasil. Acta Scient. Vet. 33:51-55.

Singh R., Yadav A.S., Tripathi V. \& Singh R.P. 2013. Antimicrobial resistance profile of Salmonella present in poultry and poultry environment in north India. Food Control 33:545-548.

Singh S., Yadav A.S., Singh S.M. \& Bharti P. 2010. Prevalence of Salmonella in chicken eggs collected from poultry farms and marketing channels and their antimicrobial resistance. Food Research International 43:2027-2030.

Tacon A.G.J. \& Metian M. 2008. Aquaculture feed and food safety: the role of the food and agriculture organization and the Codex Alimentarius. Annals N.Y. Acad. Sci. 11:50-59.

Temelli S., Kahya S., Eyigor A. \& Carli K.T. 2010. Incidence of Salmonella Enteritidis in chicken layer flocks in Turkey: Results by real-time polymerase chain reaction and International Organization for Standardization culture methods. Poult. Sci. 89:1406-1410.

Téo C.R.P.A. \& de Oliveira T.C.R.M. 2005. Salmonella spp.: o ovo como veículo de transmissão e as implicações da resistência antimicrobiana para a saúde pública. Semina, Ciênc. Agrárias 26:195-210.

Thomas M.E., Klinkenberg D., Ejeta G., Van Knapen F., Bergwerff A.A., Stegeman J.A. \& Bouma A. 2009. Quantification of horizontal transmission of Salmonella enterica serovar Enteritidis bacteria in pair-housed groups of laying hens. Appl. Environ. Microbiol. 75:6361-6366.

Van Hoorebeke S., Van Immerseel F., Haesebrouck F., Ducatelle R. \& Dewulf J. 2011. The influence of the housing system on Salmonella infections in laying hens: a review. Zoonoses Publ. Health 58:304-311.

Van Immerseel F., De Buck J., Pasmans F., Bohez L., Boyen F., Haesebrouck F. \& Ducatelle R. 2004. Intermittent long-term shedding and induction of carrier birds after infection of chickens early posthatch with a low or high dose of Salmonella Enteritidis. Poult. Sci. 83:1911-1916. 